\title{
Nowoczesne czytanie Leśmiana
}

Michał Paweł Markowski na początku książki stwierdza, że przyświeca mu przede wszystkim cel dydaktyczny ${ }^{\mathrm{I}}$. Chodzi mianowicie o nowatorskie wprowadzenie ambitnych czytelników do „polskiej literatury nowoczesnej”, a w gruncie rzeczy do polskiej krytycznej literatury nowoczesnej. Rzeczywiście, najnowsza praca znanego dekonstrukcjonisty stanowi wyborny przewodnik po tekstach Bolesława Leśmiana, Brunona Schulza i Witkacego odczytanych w perspektywie poststrukturalnej. Jedną rzecz warto zaznaczyć. Markowski pozostaje tu teoretykiem czy filozofem literatury, ukształtowanym na lekturze takich mistrzów analitycznego dyskursu, jak Jacques Derrida, ale swój wgląd w literaturę wzbogaca o refleksję antropologiczną i cywilizacyjną. Dzięki temu jego interpretacje akcentują dobitnie wymiar egzystencjalny omawianych dzieł. Wydaje się, że Markowski, coraz intensywniej romansujący z pragmatyzmem, próbuje przekonać nas, że jego ulubieni pisarze i badacze są tyleż specjalistami od tekstów kultury, co czytelnikami świata - oryginalnie ujrzanego.

„Leśmian, Schulz, Witkacy mówią nam coś ważnego o człowieku - czytamy - o jego lękach, jego nadziejach, o kłopotach z samym sobą, o pomyłkach, ale mówią nam też o kłopotach, jakie człowiek nowoczesny ma $\mathrm{z}$ rozumieniem, interpretowaniem i przedstawianiem świata" (s. 8). Chwilę później pojawia się „przekonanie autora dotyczące literatury jako takiej” (s. 9). $\mathrm{Na}$ to ukonkretnienie, ujednostkowienie tekstu literackiego chcę zwrócić szczególną uwagę: „[...] literatura zanurzona jest w naszym doświadczeniu, stanowiąc istotną część życia. Autor chciał

${ }^{I}$ M.P. Markowski, Polska literatura nowoczesna. Leśmian, Schulz, Witkacy, Kraków 2007. Numery stron podaję w tekście głównym. 
więc stworzyć taką perspektywę, by można było mówić o literaturze $\mathrm{w}$ powiązaniu $\mathrm{z}$ człowiekiem i jego najgłębszymi potrzebami i pragnieniami" (s. 9). W kolejnych zdaniach widzimy, że zakładany dydaktyzm nie ogranicza się tylko do przedłożenia wiedzy na temat zasygnalizowany w tytule: „[...] wpisując literaturę w naszą egzystencją - podpowiada Markowski - zapraszając ją do naszego życia i usuwając kontemplacyjny lub tylko z obojętności zrodzony dystans między nami a nią - można zapobiec analfabetyzacji nas wszystkich" (s. 9). Da się z tych oznajmień wyczytać Rortiańskie przesłanie: obcowanie z literaturą wyostrza naszą świadomość, uczy nas przenikliwiej patrzeć na siebie i innych, wzbogaca nasze życie intelektualne i emocjonalne, uwrażliwia na inność, którą można poznawać przez rozmowę czy dyskusję.

O wymarzonej czytelniczce Markowskiego można powiedzieć to samo, co David Herbert Lawrence mówi o swoje słynnej bohaterce, Lady Chatterley: „Ale ona chce wiedzieć, zawsze będzie chciała wiedzieć" ${ }^{2}$. Z rozumowania brytyjskiego pisarza wynika, że osoba, która „chce wiedzieć”, wiedzieć więcej i inaczej, która „zawsze będzie chciała poczytać czasem Swinburne'a”, która „nie potrafi obejść się bez rozmowy”, która „będzie zawsze chciała móc zajrzeć do literackiego dodatku «Timesa», żeby sprawdzić, czy nie ukazała się jakaś nowa, zajmująca powieść" 3 , jest szczególnie wyczulona na bezmyślne uczestniczenie w życiu, czyli bierne podporządkowywanie się oczywistościom, banałom, imperatywom, kliszom, schematom.

Sięgam do Lawrence'a, do dyskursywnego buntownika, ponieważ chcę wyraźnie podkreślić, że Markowski należy do tych modernistycznych humanistów, którzy uważają, że literatura jest także przedsięwzięciem epistemologicznym i edukacyjnym. Adresat Markowskiego to ten, który chce wiedzieć więcej, ale również być bardziej krytycznym wobec zastanej wiedzy. Stawką monografisty Nietzschego jest zachęcenie czytelników do krytycznego rozumowania. Ktoś zapyta, dlaczego tak często dzisiaj wychwala się ową zdolność. Żeby plastycznie odpowiedzieć na to pytanie, odwołam się do Zakochanych kobiet. Jeden z bohaterów tego utworu spogląda na ojca swojej wybranki:

Birkin widział w nim jedynie dziwny, niezrozumiały, nieomal chaotyczny zlepek namiętności i pragnień, ograniczeń, tradycyjnych pojęć i automatycznych sądów - wszystko to niespoiste, rozbite,

${ }^{2}$ D.H. Lawrence, Kochanek Lady Chatterley, przeł. Z. Sroczyńska, Warszawa 2008, s. 91.

3 Ibidem. 
wciśnięte w tego szczupłego o jasnej cerze, który około pięćdziesiątki był równie nijaki jak wtedy, kiedy miał lat dwadzieścia, i równie nieuformowany. Jak mógł być ojcem Ursuli, skoro nie umiał stworzyć siebie? 4

Oto jest antybohater prozaika: podmiot, który nie ma pomysłu na samego siebie i w konsekwencji skazuje się na biografię będącą bezmyślnym powtórzeniem cudzych życiorysów. Markowski jako humanistyczny rewizjonista bez przerwy odwołuje się w swojej książce do badaczy, którzy nie zaakceptowali rewolucyjnych tekstów Leśmiana, Schulza i Witkacego, którzy bali się wyjść poza utrwalone poglądy estetyczne. Złośliwy recenzent zapytałby, czemu ma służyć to permanentne wskrzeszanie konserwatywnych i często niefortunnych wypowiedzi wybitnych krytyków, które dzisiaj tak łatwo zbić. Tak czy owak, dzięki temu czytelnik może odnieść wrażenie, że według Markowskiego żyć dalej, pisać dalej to redefiniować siebie, wymyślać nowe idiomy, rzucać wyzwania tradycjonalistom. Na przekór rozmaitym siłom inercji. „Jeśli historia literatury miałaby powielać jedynie dotychczasową wiedzę na temat literackich dziejów - pisze autor - to właściwie trudno znaleźć wytłumaczenie dla jej przyszłej działalności. Wystarczyłoby przecież zaakceptować to, co już jest. Po cóż jednak powtarzać w kółko to samo?” (s. 21). W innym miejscu, po wydaniu omawianego tu dzieła, mówił: „[...] umysłowość polska jest statyczna, nie - dynamiczna; statyczna to znaczy skłonna do zasiedziałości [...]" ${ }^{5}$. Lady Chatterley myślała podobnie o swoim kochanku: „On nie ma żadnego określonego celu, do niczego w życiu nie dąży. Jest statyczny. A ona właśnie tego nie znosi. Jest statyczny" ${ }^{6}$. Literaturoznawstwo powinno być walką o życiodajny ruch, zmianę, przemieszczenie. W przeświadczeniu Markowskiego tak zazwyczaj nie jest, stąd jego bardzo ostre sądy na temat polskiej humanistyki. W cytowanym przed chwilą wywiadzie powiedział: „Rzecz ma się tak: brakuje nam nie tylko intelektualnych prowokacji, ale również śmiałości i wynalazczości” 7 . Nieco wcześniej zasugerował: „Bierze się to po części z tego, że prawie wszyscy uważają, że literaturoznawstwo jest nauką, która powinna głosić oczywistości”8.

4 D.H. Lawrence, Zakochane kobiety, przeł. I. Szymańska, Warszawa 2008, s. 295.

5 Fabuby wśrwiecie pojęć, rozmowa z M.P. Markowskim, w: R. Ostaszewski, Etapy, Olsztyn 2008, s. 280.

${ }^{6}$ D.H. Lawrence, Kochanek Lady Chatterley, s. 93.

7 Fabuby wśswiecie pojęć, s. 281-282.

8 Ibidem, s. 281. 
Zaznacza się w tej inspirującej pracy (i nie tylko w tej przecież) głęboka potrzeba ustanowienia siebie jako badacza nowatorskiego i niezwykle wpływowego. W pewnym sensie to nie powinno dziwić. Między innymi dlatego, że przecież Markowski dużo wie o potędze języka performatywnego. Jeden $\mathrm{z}$ bardziej krewkich, ale i kłopotliwie antynowoczesnych polskich literaturoznawców o proweniencji strukturalistycznej przezwał kiedyś autora Występku heroldem ponowoczesności. No cóż, złośliwość ta jest chyba do pewnego stopnia uzasadniona. Markowski tak oto komentował swoją Polska literaturę nowoczesna: „Chodzi mi o stworzenie czegoś w rodzaju Wulgaty na profesjonalnym poziomie - czego, moim zdaniem, brakuje w naszej nauce o literaturze" 9 . Czyż nie jest to dowód na to, że Markowski chce być autorem kanonicznych wykładni? Używana przez badacza retoryka pozwala stwierdzić, że jego praca jest manifestacją własnej oryginalności. Wszak ładunek merytoryczny, często znakomitej próby, jest nieprzerwanie konwojowany przez język autopromocji, który pewnie wielu w takiej dawce uznaje za zbędny. Ale przecież ta cecha daje do myślenia. Nie mogę pominąć milczeniem faktu, że Markowski nie szczędzi samemu sobie pochwał. Już na stronie piątej określa, na czym polega „zasadnicza innowacyjność” wykładu wobec „tradycyjnego ujęcia”. Na szóstej pozwala przeczytać książkę jako „zbiór trzech nowoczesnych monografii nowoczesnych pisarzy”. Na siódmej zaś oznajmia: „Książka ta stanowi wstęp do nowej interpretacji dziejów dwudziestowiecznej literatury polskiej” - to podkreślenie nie jest moje. Tego rodzaju inkantacji jest znacznie więcej. Janusz Sławiński, jeden z najwybitniejszych strukturalistycznych teoretyków, pancerny literaturoznawca, nieustannie podważał asertoryczność swoich naukowych wypowiedzi, tymczasem Markowski, adorator słabych teorii, piewca końca „wielkich narracji”, jawi się niemal jako retoryczny konkwistador czy kolonizator $^{\text {Io }}$. To zaskakujące.

Poza tym wcale nie aż tak bardzo, skoro w przywoływanym już wywiadzie teoretyk mówił z żalem i ką́sliwie, że polska umysłowość „to nie jest umysłowość kolonizatorska, lecz zadomo-

9 Ibidem, s. 288.

тo Czasami zabawnie agresywny. Oto fragment z książki M.P. Markowski, Jacques Derrida i literatura, Kraków 2003, s. 398: „Gdyby [...] Erazm Kuźma zaczął twierdzić (co oczywiście nigdy nie nastąpi), że Marcel Proust ukończył całe swoje dzieło przed śmiercią i dlatego znany nam układ tomów Poszukiwania jest nienaruszalny, i na podstawie tego faktu napisałby coś o wpływie magicznej siódemki na symbolikę powieści Prousta, to wtedy rzuciłbym mu się do gardła i napisał własną, miażdżącą wykładnię, opartą na historycznych faktach i filologicznej analizie pozostawionych przez Prousta brulionów”. 
wiająca-się, co oczywiście ma fatalny wpływ na jakość dysput intelektualnych w Polsce" ${ }^{\text {II }}$. Być może zatem ta ryzykowna retoryka, będąca jego znakiem markowym niemal „od zawsze”, jest po prostu dowodem na to, że autor Anatomii ciekawości to rasowy modernista, niepotrafiący nie przekonywać tak właśnie do swojego sposobu myślenia, z którego jest najwyraźniej szalenie ukontentowany. Rozpoznanie, że Markowski to idiosynkratyczny humanista, jest dla mnie bardzo ważne. Taki stan rzeczy ma przecież wpływ na kształt interpretacji poszczególnych tekstów literackich. Sam autor przy różnych okazjach podkreśla, że teoria interpretacji łączy się z poglądem na świat, „odpowiada naszej osobowości”, że „dostarcza języka pozwalającego lepiej wysłowić siebie i nurtujące nas problemy" ${ }^{\text {I2. }}$.

Zanim jednak przeanalizuję, jak Markowski odczytuje poezje Leśmiana - Witkacego i Schulza biorę w nawias - zreferuję pokrótce, co Markowski „wie” o krytycznej nowoczesności i co my, czytelnicy, powinniśmy „wiedzieć” po lekturze jego imponującej książki. Owa wiedza jest szalenie istotna, ponieważ programuje tryb lektury.

„Na czym polega krytyczna nowoczesność?” - zapytuje Markowski w podtytule Podsumowania i zaraz klarownie odpowiada. Otóż „nowoczesność krytyczna jest wytworem kryzysu w obrębie dwudziestowiecznej nowoczesności”. Kryzys ten polegał „na postawieniu dramatycznego pytania o granice przedstawialności świata”. W konsekwencji doszło „do powstania czterech zasadniczych nieufności, których splot daje w efekcie zróżnicowaną, choć dość spójną ideologię mimetyczną" (s. 397). Zanim je przytoczę, nadmienię tylko, że według Markowskiego są one „wymierzone” przeciwko przeświadczeniu, „iż możliwe jest dotarcie poprzez jakiekolwiek kulturowe przedstawienie rzeczywistości do niej samej, wolnej od jakichkolwiek reprezentacji” (s. 402). Jak widzimy, Markowski lubi raz po raz ujawnić swoje zamiłowanie do militarnego stylu uprawiania humanistyki. Pierwsza nieufność sprowadza się do sprzeciwu "wobec koncepcji świata gotowego i już ukształtowanego" (s. 397). Krytyczna nowoczesność zakłada, że świat nie tyle jest, co bezustannie staje się, wydarza, reorganizuje. Wynikać z tego ma wniosek, że „literatura nie przedstawia rzeczywistości (bo przedstawić może tylko to, co jest)". Pojawia się więc znamienny imperatyw: ,[...] używane formy literackie powinny dostosować się do płynnego statusu rzeczywistości i odwrotnie: dyna-

\footnotetext{
II Fabuly wírwiecie pojęć, s. 280.

I2 Ibidem, s. 283.
} 
miczne formy mówienia ustanawiają dynamiczną rzeczywistość, która jest efektem artystycznej inwencji” (s. 398). Dlatego dzieła pisarzy nowoczesnych są tak dziwne, oryginalne, zdumiewające, po prostu wysoce idiomatyczne. Druga nieufność wyraża się w alergicznej niechęci do „przyjmowanych $\mathbf{z}$ góry przeświadczeń na temat rzeczywistości”. Sztuka nie może potwierdzać pewników, które zdążyły się już zinstytucjonalizować i zadomowić na trwałe w naszych głowach oraz osadzić, by tak rzec, na naszych językach. „Sztuka ma za zadanie wytrącenie z oczywistości”. Sztuka ma się opowiadać za „odnawianiem myślenia" (s. 399). Tu nie można pominąć faktu, że bohaterowie Markowskiego są stanowczo antyawangardowi. Dlaczego? Otóż między innymi dlatego, że awangardziści ekstatycznie i, jak rozumiem, bezkrytycznie „przytakiwali” teraźniejszości, która wynalazła znienawidzoną przez Leśmiana, Schulza i Witkacego kulturę masową, czyli perwersyjne zaprzeczenie wysoce osobnej formy bycia w świecie. Trzecia nieufność dotyczy „jednoznaczności świata danego poznaniu”. Główną motywacją do działania artystycznego jest dla przedstawicieli krytycznej nowoczesności zaciekawienie, zdziwienie, zdumienie światem, który nieodmiennie zaskakuje wielością swoich oblicz. Powiada Markowski, że „kluczowe dla ich koncepcji doświadczenia jako «defamiliaryzacji świata» jest pojęcie tajemnicy” (s. 400). Dodaje również, że „dla pisarzy nowoczesnych nagła manifestacja tajemnicy nie odsyła do nieskończonego bytu, lecz do skończonego bycia, do przygodnej ludzkiej egzystencji, w której objawia się inny, nieprzewidziany sens" (s. 401). Z takiego punktu widzenia świat jest niepoznawalny, a egzystencja stanowi nierozwiązywalną zagadkę. W tej sytuacji ambitna literatura musi być wieloznaczna i niekonkluzywna. Czwarta nieufność zapowiada gwałtowną rozprawę z przekonaniem o ,jednoznacznie uchwytnej pozycji podmiotu, zarówno podmiotu pisarskiego, jak i tego, kto mówi w utworze literackim" (s. 401). Wiąże się to z głębokim przeświadczeniem „o niegotowości człowieka”. Innymi słowy, to na początku XX wieku przygotowuje się rebelię pod hasłem „kres człowieka”. Wszak podmiot wtedy „przestaje już być źródłem wszelkich przedstawień «Ja» (koniecznie opatrzone cudzysłowem), istnieje o tyle, o ile ciagle tworzone jest w procesie kreacji coraz to nowych własnych wizerunków, spośród których nie sposób jednoznacznie wybierać wedle kryterium maksymalnej adekwatności wobec «ja» prawdziwego" (s. 402). Do owych czterech nieufności koniecznie trzeba dodać jedną pewność, rządzącą wszystkimi, jak się zdaje, tekstami Markowskiego. Otóż przedsięwzięcie intelektualne tego autora 
jest konsekwencją „zwrotu lingwistycznego” czy też tekstualnego. Warto zatem wskazać priorytetową rolę języka w krytycznej nowoczesności, do której automatycznie przypisuje się sam Markowski. „Język (forma) nie jest wtórny wobec rzeczywistości - stwierdza teoretyk - albowiem to dzięki niemu może ona zaistnieć, czyli nabrać sensu" (s. 218). Badacz odwraca obiegową formułę i oznajmia, że język jest uprzedni wobec rzeczywistości: „[...] rzeczywistość - jak u Leśmiana - podąża za słowem" (s. 218). Zatem nasze odczuwanie, widzenie, myślenie są zapośredniczone przez język. „Dlatego ontologia - dowodzi Markowski - jest jednocześnie filologią i odwrotnie: filologia jest ontologią, badaniem tego, co jest, poprzez język" (s. 218). Podsumowując charakterystykę omawianej formacji, badacz stwierdził: „Nowoczesność krytyczna pochłonięta jest pytaniem: jaki status ma rzeczywistość, która nas otacza? Jak można ją przedstawić? Kto i jak to robi? W jakim celu? Jakimi środkami?" (s. 402).

Tak właśnie wygląda podstawa historyczno-teoretyczna, na której badacz prezentuje dorobek genialnych pisarzy. Ten, kto sięgnie po podręcznik, zorientuje się, że owa konstrukcja jest wspaniale rozpisana. Zazdroszczę młodym adeptom literaturoznawstwa, że mogą zaczynać swoją przygodę od lektury takiej „wulgaty”, księgi bogatej w konteksty, także pozaliterackie, odsyłającej do imponującej bibliografii, podsuwającej światowe rozwiązania. Jednak bardziej doświadczony czytelnik, szczególnie wieloletni czytelnik samego Markowskiego, może czuć się zobligowany do zgłoszenia kilku zastrzeżeń. Pierwsze jest związane z postulatem oryginalności. Wizja modernizmu, proklamowana przez Markowskiego, na tle polskich praktyk dydaktycznych bywa wizją zbawiennie rewolucyjną. Jednakowoż w kontekście literaturoznawstwa uprawianego na świecie, a zapisanego w książkach, do których dzisiaj mamy łatwy dostęp, traci ona blask nowatorstwa, jawi się raczej jako dość posłuszne powtórzenie cudzych narracji. „My to już wiemy skądinąd” tak można by zareagować na komunikat, jakim jest Polska literatura nowoczesna. Co więcej, Markowski zasadniczo nie wychodzi poza krąg zagadnień, który zarysował w swoich pierwszych ważnych książkach. Pewne doprecyzowania, drobne przekierowania niczego istotnego tu nie zmieniają. W gruncie rzeczy teoretyk nie posuwa spraw naprzód. $\mathrm{Z}$ tego powodu pojawia się możliwość postawienia pytania o to, czy jego własna myśl krytyczna jest rzeczywiście aż tak bardzo krytyczna, skoro powiela wypracowane i dopracowane formuły. Podmiot krytyczny ma stawiać pod znakiem zapytania wszystkie koncepty, ale pod- 
miot wyłaniający się z najnowszej propozycji Markowskiego to podmiot, który potwierdza swoje osiągnięcia, niekwestionowane oczywiście. Ktoś powie, że podręcznik to nie miejsce na zasadnicze rewizje. $Z$ całą pewnością, ale przecież książka ta jest anonsowana właśnie jako projekt nowatorski. W moim przekonaniu myśl krytyczna powinna od czasu do czasu poddawać siebie sprawdzianom, aby nie wpaść $\mathrm{w}$ koleiny i w efekcie nie celebrować samej siebie. Markowski, jak wielu fundatorów, pod tym względem wcale nie jest niewinny. Jego refleksja jest ciągle przydatna, inspirująca, potrzebna, ale również przewidywalna. Stabilizuje się jako doktryna. A to ma niepokojący wpływ na czytanie literatury: z góry możemy przewidzieć, jak Markowski przeanalizuje i zinterpretuje dany tekst. Widzę w tym duże zagrożenie, bo w konsekwencji poezja zostaje odarta z nieokreśloności i zamienia się - mimo wszelkich ukonkretniających zaklęć - w ilustrację poglądów teoretycznych.

Twierdzę, że Markowski rozpatruje na tym tle twórczość autora Sadu rozstajnego i przeobraża ją w medium służące do udzielania odpowiedzi na przytoczone wcześniej pytania. Odpowiedzi, które wynikają z doktryny, a niekoniecznie z wierszy. Markowski jest bardzo klarownym, wyrazistym, filozoficznym i narcystycznym umysłem i chyba dlatego w momencie, w którym nazwał pewien korpus dzieł „polską literaturą nowoczesną", z miejsca zinterpretował ją, sklasyfikował, utwierdził w jednoznaczności i w zastanawiającej mierze „odkrytycznił”. Jego doktryna często przyciąga uwagę jako domena uogólnień. Ten zarzut może szczególnie zaboleć badacza, bardzo często powtarzającego za Derridą, że tekst literacki stanowi zaskakujące spotkanie z czymś niespodziewanym, co ma władzę przeobrażania naszego sposobu myślenia, mówienia, pisania, bycia. Mówię tu teraz o takiej sytuacji, w której czytamy - na przykład wiersz Percy'ego Shelleya Na śmierć i spotykamy nagle dziwną linijkę: „Świat ten jest niańką wszystkiego, co wiemy” („This world is the nurse of all we know" $)^{\mathrm{I} 3}$. Żeby oddać sprawiedliwość swojemu pomieszaniu estetycznemu i intelektualnemu, czytelniczej dezorientacji, uczeń Derridy będzie chciał w jakiś szczególny sposób zaznaczyć oryginalność swojego odbioru, który osłabi pokusy tetycznej i całościującej pointy, będzie chciał przedstawić mnogość odczytań owego wersu, udowodnić jej niewyczerpywalność. Wers jest zaskakujący i powinien chyba taki w istotnym stopniu pozostać. Chcąc zadośćuczynić

I3 P.B. Shelley, Na śmierć, przeł. W. Lewik, w: idem, Poezje wybrane, Warszawa 1961, s. 12. Wersja oryginalna: http://www.gutenberg.org/wiki/Main Page. 
temu zadaniu, niemal niewykonalnemu, trzeba zdecydować się, jak sądzę, na wielokrotną, nieustającą, wewnętrznie sprzeczną analizę, tymczasem Markowski w swojej książce koncentruje się przede wszystkim na analizie fragmentów, z których można wyciągnąć wyostrzoną dyskursywną lekcję. W konsekwencji zapamiętujemy Leśmiana jako posiadacza wyrazistych poglądów. Ma to oczywiście swoje zalety, ale rasowy dekonstrukcjonista nie przecenia przecież ich wartości. Moje zastrzeżenia sprowadzają się zatem do sugestii, że krakowski literaturoznawca, który potrafi świetnie przedyskutować wiele skomplikowanych kwestii z zakresu nauk humanistycznych, pchnąć nasze czytanie na nowe tory, nie zawsze zachwyca podczas lektury tak drobnych, kruchych, poszczególnych istnień, jak wiersze. Naturalnie, zdaje sobie on sprawę, że przy czytaniu liryków należy „zachować ostrożność, nie dając się skusić generalizacjom" (s. 137), ale zbyt często nie umie oprzeć się czarowi tychże generalizacji. Przestrzegałbym przed tą silną inklinacją do uogólnień, która zanadto stabilizuje wiersze i w konsekwencji zamienia je w media całkiem przewidywalnej wiedzy. Owszem, lektura Polskiej literatury nowoczesnej osiąga swój cel, albowiem jej czytelnicy gładko opanowują wiedzę o krytycznej nowoczesności, wręcz moszczą się w niej jak w przytulnym gniazdku, ale równocześnie zatracają instynkt idiomatycznej lektury. Dobrym przykładem może być analiza wiersza Przed świtem:

Trwa jeszcze ciemne rano -

Śpi niebo nad altaną.

Staw błysnął o dwa kroki Już widać, że głęboki.

W łopuchu czy pokrzywie Świerszcz dzwoni przeraźliwie!

Rozpoznajże w ciemnocie, Czy wróbel tkwi na płocie?

Kształt wszelki wybrnął z cienia,

Lecz nie chce mieć imienia.

Chce snom się jeszcze przydać:

Nie widać nic, a - widać ${ }^{14}$.

I4 B. Leśmian, Przed świtem, w: idem, Poezje wybrane, oprac. J. Trznadel, Kraków 1983, s. 194. 
Markowski stwierdza, że wiersz „nie ma ogólnej treści, lecz jest zapisem jakiejś konkretnej sytuacji”. Zaraz potem sugeruje, że niepodobna odpowiedzieć na pytanie, jakiej sytuacji. „Żadnej pewności” - tak brzmi pierwsza konkluzja. W mig okazuje się jednak, że „wiersz w dystychu «Kształt wszelki wybrnął $\mathrm{z}$ cienia/ Lecz nie chce mieć imienia» mówi nam coś o relacji między kształtem a imieniem, między światem a językiem”. Wiersz jest zatem o tym, „że czlowiek patrząc na świat jednocześnie światu nadaje nazwy” (s. 111). Co więcej, „dlatego ostatnie zdanie brzmi: «Nie widać nic, a - widać», albowiem nic nie widać na pewno, bo wszystko zanurzone jest w ciemności, ale też widać, albowiem wszystko zostało już powiedziane" (s. 112). Zastanawia mnie ten przeskok od interpretacji, będącej domeną niepewności, do komentarza, który jest przysłowiowym wyłożeniem kawy na ławę, w dodatku wyłożeniem problematycznym. Bo czy rzeczywiście Leśmian wyraża tu myśl, że „człowiek patrząc na świat jednocześnie światu nadaje nazwy”? Owszem, sugeruje się tu ważność relacji między istnieniem a językiem, ale przecież nic się nie mówi ani o człowieku, ani o sytuacji nazywania. Gdy poeta zmierza w stronę konkretu, literaturoznawca - w stronę abstrakcji, filozoficznego problematu. $\mathrm{W}$ wierszu pewna poślednia forma bytu wydostaje się $\mathrm{z}$ domeny niedocieczoności z nadzieją, że będzie wiodła dalsze życie bez brzemienia nazwy własnej, że będzie miała ciągle kontakt ze sferami onirycznymi. Jest tu zatem mowa o pragnieniu, woli istnienia nieco bardziej konkretnego, ale jednak niezinstytucjonalizowanego. Wytłuszczony komentarz Markowskiego, choć pomocny, jednak zbyt łatwo grawituje w stronę nowoczesnych rozwiązań i zbyt pospiesznie pointuje zagadkowość dwuwersu. Glosa do ostatniej linijki również sprawia wrażenie apodyktycznej; wszak Leśmianowski oksymoron wzbudza w nas przede wszystkim potrzebę zapytywania o rozmaite szczegóły, której nie można zaspokoić tak stanowczo. Jak się ma linijka do innych scenek, jak ją odnieść do sytuacji kształtu, czy ona ma rzeczywiście związek z imieniem albo jego brakiem? Każdy z nas pewnie zadałby jeszcze inne pytania problematyzujące zagadnienie. Ktoś nawet mógłby się pokusić o stwierdzenie, że Leśmian miał po prostu słabość do nielogicznych konstrukcji, dlatego właśnie tak, a nie inaczej zamknął wiersz, ,i tyle”.

To błyskotliwe, ale zarazem zbyt nonszalanckie (bo chyba lekceważące idiomatyczność poety) odczytanie nie jest wyjątkiem. Markowski często ulega urokom dyskursywnych podsumowań. Wskażę kilka przykładów. Na stronie dziewięćdziesiątej dowiadujemy się, że „poezja Leśmiana [...] nie zakłada uprzed- 
niości świata wobec percepcji i percepcji wobec mówienia. Leśmian bowiem powiada: widzę to tylko, co mówię. Nie jest tak więc, że najpierw widzę, potem mówię. Jest odwrotnie: mogę coś zobaczyć tylko poprzez słowa, «poprzez śpiew»”. W innym miejscu czytamy, że

Leśmiana łączy $\mathrm{z}$ fenomenologią nieustanne zawieszanie tezy naturalnego nastawienia do rzeczywistości. Trzeba, powiadają fenomenologowie, zrezygnować $\mathrm{z}$ doświadczenia potocznego i wziąc świat potoczny w nawias, redukując go do tego, co istotne. Podobnie Leśmian: świat potoczny znika, by mógł pojawić się świat oczyszczony, świat pełen sensu. (s. 106)

Dodaje jednak Markowski, że świadomość lingwistyczna Leśmiana ma antyfenomenologiczne konsekwencje: „W ten bowiem sposób Leśmian [...] przechodzi od paradygmatu wzrokocentrycznego do audialnego, patrzenie zastępuje słuchaniem, prozę - poezją, a pojęcia - śpiewem" (s. 106-107). Z opowieści badacza dowiadujemy się, że Leśmian, „nie mówiąc o tym wprost, wybiera sztukę przeciwko zbawieniu, poezję przeciwko nicości, egzystencję przeciwko życiu wiecznemu" (s. 132). Analizując wątek miłosny, Markowski oznajmia: „Istnienie ludzkie jest wybrakowane, ułomne, kalekie. Tak mówi człowiek nowoczesny i Leśmian bez wątpienia wpisuje się w linię myślenia o egzystencji niepełnej, pozbawionej własnej istoty albo umieszczającej własną istotę gdzie indziej" (s. 133). Na stronie sto trzydziestej piątej pojawia się takie oto stwierdzenie: „Wydaje się, że u Leśmiana egzystencja jest nieprzepracowaną żałobą po utracie sensu". Parę stron dalej czytamy:

Na tym, zdaje się mówić Leśmian, polega okrutny paradoks śmierci: śmierć jest tym, co najbardziej nasze, ale jednocześnie tym, co pozbawia nas nas samych. Śmierć wywłaszcza nas z nas samych i dlatego nie daje się zrozumieć, albowiem rozumieć to przykrawać coś nieznanego do znanego, obcego i własnego. (s. 141)

Wszystkie te spostrzeżenia, pożytecznie uwypuklające ważne aspekty dzieła Leśmiana, zamieniają go jednak w niewolnika pewnych przekonań filozoficznych, prekursora podmiotów nowoczesnych, ponowoczesnych, poststrukturalistycznych, dekonstrukcjonistycznych, postmodernistycznych etc., klarownego i spójnego myśliciela o wyostrzonej świadomości, poetę, idącego prosto do celu, człowieka, który najważniejsze rzeczy już wie, kogoś, kto nie zaskakuje, a tylko przytakuje temu, co 
i my akceptujemy. Paradoksalnie, uwolnienie Leśmiana $\mathrm{z}$ rąk tradycyjnych badaczy spowodowało, że stał się on nazbyt aktualny, wczesny, oswojony, tożsamy z nami, bezkrytyczny wobec naszych idei. Można by zadać pytanie, czy akurat te właśnie aspekty stanowiły o specyfice Leśmianowskiej poezji, czy owa domniemana nadświadomość retoryczna była jej główną siłą. Wymowne jest też i to, że Markowski jako czytelnik poezji przekonuje najbardziej wtedy, gdy skupia się na akustycznych walorach wierszy i pisze na przykład, że „w poezji Leśmiana niczego nie widać, ale wszystko słychać" (s. 107). Dla miłośników poezji to są wspaniałe zdania, bo wskazują, na jakie istotności retoryczne warto zwracać uwagę. Markowski jednak zazwyczaj takie gesty podcina, tłumacząc swoje błyskotliwe spostrzeżenia na język filozofii, który znamy aż nadto dobrze.

Ironiczne jest zatem to, że autor, poświęcający swoją książkę pisarzom, którzy wybrali jednostkowość „przeciwko pojęciowym generalizacjom" (s. 107), tak spektakularnie wybiera owe generalizacje kosztem wychwalanej jednostkowości. Swoje omówienie tej cennej książki chciałbym zakończyć podkreśleniem paradoksu, który określa Markowskiego jako czytelnika literatury. W tym celu wrócę do Ekskursu o interpretacji, metodologicznego rozdziału Polskiej literatury nowoczesnej. Autor zestawia dwa krótkie wiersze, Trzy stowa najdziwniejsze Wisławy Szymborskiej i Krzywdę Leopolda Staffa. Lapidarna analiza porównawcza służy mu do sformułowania odpowiedzi na pytanie: „Co to znaczy interpretować utwór literacki, co to znaczy interpretować wiersz?” (s. 71). Owe rozważania są również wskazaniem, które wiersze teoretyk ceni najbardziej, a które najmniej. Silna waloryzacja jest powiązana $\mathrm{z}$ analizą. Omówienie wiersza Staffa zdradza nam, jakie teksty Markowski faworyzuje. Oto wybrany utwór:

\section{Mój mądry piesek}

Przeżył swe krótkie życie

Nie wiedząc nawet,

Że świat jest zagadką ${ }^{15}$.

Badacz dopatruje się w nim jednej zagadki, „,na którą wskazuje tytuł”. „Krzywda? - powiada - Ale czyja krzywda? Kto doznał krzywdy? Albo kto ją wyrządził? Poeta, obarczony gorzką wiedzą o niepoznawalności świata i dlatego mniej mądry od psa,

I5 L. Staff, Krzyzwda, w: idem, Wybór poezji, oprac. M. Jastrun, Kraków 1985, s. 250. 
czy też pies, który nie dowiedział się nigdy, że świat jest zagadką? O czyjej krzywdzie tu mowa? Poety czy psa?” (s. 70-71) Armia pytań konwojuje ważne przesłanie: „W tym sęk, że nigdy, na podstawie samych słów wiersza (a nie mamy innej sposobności) nie dowiemy się na pewno, o czyją krzywdę tu chodzi, albowiem obydwie hipotezy są równie zasadne" (s. 71). Okazuje się zatem, że wartościowy wiersz to taki, który, pozbawiony solenniejszego kontekstu, wywołuje w czytelniku potrzebę zadawania pytań, na jakie nie ma prawomocnych odpowiedzi: „Ta niepewność właśnie otwiera przestrzeń interpretacji” (s. 71). Dobry wiersz to medium niewiedzy, zarówno autora, jak i czytelnika. Gdy nie rozumiemy tekstu, „wtedy właśnie zaczynamy interpretować” (s. 71). No właśnie, ale co to znaczy interpretować? Przyznam, że nie do końca rozumiem wyjaśnienia Markowskiego, a z lektury analizowanej tu książki wynika wniosek, który mógłby rozeźlić autora, albowiem interpretacja w wykonaniu jego samego to przekład konkretu poetyckiego na dyskurs teoretyczny, to przeobrażenie figur niewiedzy $\mathrm{w}$ figury wiedzy, wyjaśnienie niejasności. Interpretacja zatem jawi się jako nieprawomocne, ale apodyktyczne ufilozoficznienie wiersza.

Utwór Szymborskiej w oczach Markowskiego to wehikuł treści banalnych, dlatego otrzymuje negatywną ocenę. Zerknijmy na liryk.

Kiedy wymawiam słowo Przyszłość,

pierwsza sylaba odchodzi już do przeszłości.

Kiedy wymawiam słowo Cisza, niszczę ją.

Kiedy wymawiam słowo Nic,

stwarzam coś, co nie mieści się w żadnym niebycie ${ }^{\mathrm{I}}$.

Po przytoczeniu tekstu noblistki Markowski pyta: „Czy potrzebna jest interpretacja tego wiersza?” (s. 70). Odpowiedź brzmi następująco: „[...] wydaje się, że sens jest oczywisty i całkiem dobrze go rozumiem" (s. 70). Cały akapit to okrutny, przewlekły werdykt: wiersz jest dramatycznie oczywisty. „Czy jest coś w tym wierszu niezrozumiałego, co domagałoby się interpretacji? Nie” (s. 70). O co więc w nim chodzi? „Chodzi o sprzeczność między tym, że powiedziane i tym, co powiedziane. Mówienie o ciszy zabija ciszę, mówienie o przeszłości

I6 W. Szymborska, Trzy stowa najważniejsze, w: eadem, Chwila, Kraków 2002, s. 14. 
likwiduje ją, mówienie o nicości niweczy nicość. I tyle” (s. 70). Swoją ocenę zamyka Markowski pytaniem retorycznym: „Czy to nie oczywiste?” (s. 70). W pierwszej chwili ucieszyłem się, że w znakomitym i popularnym podręczniku ktoś wreszcie odważył się zaczepić gigantycznie przecenioną poetkę i jej płaski formalnie wiersz. Wkrótce jednak zrozumiałem, że takie postawienie sprawy zaprzecza założeniom dekonstrukcjonizmu, także założeniom samego Markowskiego. Teoretyk wszak odczytuje przeciętny tekst nazbyt dosłownie, dlatego nie dostrzega jego niejasności, która bierze się z figuratywnej natury języka. W znanym powszechnie wywiadzie Paul de Man powiedział: „[...] żadnego tekstu nie można wyczerpać bądź nasycić, albo w pełni zrozumieć” ${ }^{17}$.

Twoje lektury - stwierdzał dalej amerykański badacz - będą zawsze nazbyt określone w tym sensie, że skończysz na kilku mniej lub bardziej niewspółmiernych odczytaniach, albo niedookreślone w tym sensie, że nawet nie zbliżysz się do czegoś, co mogłoby wydawać się znaczeniem. Nigdy więc nie jesteś całkiem na miejscu ${ }^{\mathrm{I}}$.

$\mathrm{Z}$ rozumowania autora Alegorii czytania wynika, że każdy tekst, przeczytany wielokrotnie, jest tekstem zironizowanym, a wobec tego tekstem, który skutecznie broni się przed jakąkolwiek próbą ostatecznego omówienia go. De Man podpowiada zatem, że żadnego tekstu nie można skwitować zbywającym słówkiem „tyle”.

Kiedy wczytuję się w tekst Szymborskiej, uprzytamniam sobie, że jest to prawomocna konstatacja. Bo czy rzeczywiście „więcej nie da się o tym wierszu nic powiedzieć ponad to, że trzykrotnie poetka podkreśla rozbieżność mowy, czyli tego, co jest, i tego, co nie ma" (s. 70)? Jedna ze studentek zwróciła uwagę, że ten wiersz wrzuca na warsztat trzy metafizyczne kategorie i demaskuje je jako puste tropy. W tym ujęciu wiersz to przedsięwzięcie krytyczne, którego konkluzja brzmi następująco: słowa skazane są na samoodniesienie, stoją w sprzeczności z tym, co głoszą, wobec tego zadaniem słów jest analiza swoich własnych retorycznych postępków. Uważam, że takiej lektury można śmiało bronić. Co więcej, jestem przekonany, że to dekonstrukcjonistyczne tropienie tekstu można ciągnąć dalej. Wszakże, jeśli wiersz wskazuje na swoją niewiarygodność, to czy można przy-

${ }^{7}$...dla mnie tak, skoro nazywam sie de Man..., z P. de Manem rozmawia R. Moynihan, przeł. A. Przybysławski, „Literatura na Świecie” 1999, nr 10-11, s. 250.

I8 Ibidem. 
jąć za dobrą monetę demaskację jego skłamanej performatywności? Co zatem ten wiersz robi? Jak go należy rozumieć? Co jest jego celem? Jak to wszystko ma się do Szymborskiej i jej poezji, nowszej i tej wcześniejszej? Czytelnicy de Mana wyczują, że pośród tych pytań powoli budzi się ironia. Pieprzyku sprawie dodaje fakt, że wiersz Szymborskiej można skomentować słowami Markowskiego, pochodzącymi z książki o Derridzie:

[...] wiersz ten nie przedstawia niczego, niczego nie re-prezentuje, bo przedrostek re-, zakładający uprzednią obecność tego, co re-prezentowane, właściwie użyty jest $\mathrm{w}$ tym zdaniu bezzasadnie. Tekst ten jest bez wątpienia referencjalny (bo żaden tekst nie jest niereferencjalny), tym jednak, do czego odsyła, nie jest żaden realnie istniejący poza nim referent. Co jest więc „przedmiotem” odniesienia? Sama referencja: jej mechanizm, jej procesualność i jej problematycznośćs ${ }^{19}$.

Czy ta moja/nie moja analiza nie jest oczywista? Dzisiaj, kiedy przeczytaliśmy dziesiątki tekstów o dekonstrukcji, pewnie tak, ale chyba pokazuje jednak, że wiersz Szymborskiej wbrew osądowi Markowskiego nie jest pozbawiony swoistych głębi. Wymowne jest, że zarzut dotyczy poziomu dyskursywnego, nie zaś estetycznego. Wychodzi więc na to, że owo wierszowe medium, jakkolwiek niezbyt atrakcyjne, jest medium nie tyle apodyktycznej wiedzy, ile zironizowanej wiedzy. Może więc jest to jednak dobry wiersz? Czyżbyśmy zatem mieli tutaj do czynienia z pokusą pospiesznej i złośliwej oceny idiomu, którego, z całkiem zrozumiałych powodów, nie cenimy? Czy nie świadczy to więc o tym, że Markowskiego w tekstach interesuje słynne „co”, a nie legendarne „,jak”? Czyż zatem Markowski nie jest tym, za kogo się podaje? Czym jest wobec tego interpretacja? Czym Polska literatura nowoczesna? Na te i inne pytania, multiplikujące się w trakcie lektury, każdy z nas musi odpowiedzieć sobie sam. Moje zadanie właśnie się skończyło: swoje pytania zadałem, oznajmienia sformułowałem. „I tyle”.

\section{MiCHA£ LAREK}

\section{Modern reading of Leśmian}

The text discusses critically the analyses of Leśmian's poems carried out by Markowski in his Polska literatura nowoczesna [Polish modern

I9 M.P. Markowski, Jacques Derrida i literatura, s. 219. 
literature]. The critical evaluation focuses on the following four key assumptions (and convictions) presented by Markowski: 1 . literature is an epistemological and educational task that aims at promoting and teaching critical thinking; 2. the history of literature involves permanent re-rendering of interpretative techniques; 3 . literary text is ambiguous because it cannot be generalized and is a record of human experience, both existentialist and intellectual; 4 . interpretation should testify to the idiomatic nature of the text. In the course of reading the book, however, it turns out that on more than one occassion Markowski is inconsistent and even contradicts himself. As a result, he lays himself open to charges suggesting that he does not consistently stick to his methodological postulates, sometimes even contradicting them. The article is concluded with a suggestion that the image of the literary critic as a diligent deconstructionist is badly shaken. Markowski is more interested in philosophical aspects in a literary work than in its aesthetical value. The text represents thus a revisionist and debunking contribution to the readings of this "harbinger of postmodernity".

MICHAL LAREK - dr, adiunkt w Zakładzie Literatury i Kultury Nowoczesnej IFP UAM, krytyk literacki, literaturoznawca, redaktor „Czasu Kultury”. Publikował m.in. w „Tekstach Drugich”, „Kresach”, „Studium”, „Tekstualiach”, „Teatrze”. Zajmuje się literaturą (przede wszystkim poezją) $\mathrm{XX}$ wieku, teorią literatury, kulturą popularną, nowymi mediami. Wydał (z Jerzym Borowczykiem) tom wywiadów z pisarzami Rozmowa była możliwa (2008), współredagował tom Kres logocentryzmu i jego kulturowe konsekwencje (2009).

e-mail:michal.larek@gmail.com 